M. André Aubréville, formerly inspecteur-général des eaux et forêts de France Outre-mer, described how the influence of past climates is still apparent in the existence of relict species and savannah areas within what is now the high rain forest zone. But in a paper entitled "Derived Savannah-Derived from What ?" by Mr. R. W. J. Keay, principal research officer in the Nigerian Forest Research Department, the difficulty of distinguishing between relict and derived savannah areas was emphasized. The influence of man on the environment was also discussed by Prof. J. F. V. Phillips, of the University College of Ghana. It was apparent that much further work would be necessary before the relative importance of climatic changes and the activities of man on the vegetation of West Africa could be defined.

The probable relations of climatic and vegetational changes to the distribution of the mammalian fauna in past and present times was described by M. P. L. Dekeyser, head of the Zoology Section of the Institut Français d'Afrique Noire, and in a paper by the late Mr. Angus Booth. Mr. Booth, who was lecturer in zoology in the University College of Ghans and secretary to the Conference, died on March 16 after s short illness. During his six years in West Africa he had become the leading authority on West African primates.

In these papers the presence of relict faunas and the distribution of mammalian fossils provided further evidence for a succession of pluvial and interpluvial periods, but once again the dating of these periods was extremely difficult.

In summary, it may be said that while there was no indication of any disagreement in the probable succession of climatic changes as proposed by Sir George Simpson in his "Further Studies on World Climate" (Quart. J. Roy. Meteor. Soc., 83, 459; 1957), and ample evidence from a variety of sources to substantiate the theory that a succession of pluvial and interpluvial periods has occurred in the tropics, corresponding to the glacial periods of the temperate zone, further fundamental research into the geology, pedology, archæology, phytogeography and zoogeography is necessary before any well-defined chronological sequence can be established. The great. importance of the succession of pluvial and interpluvial periods to a proper understanding of the natural history of this and other parts of Africa is very evident.

D. J. Greentand

\title{
AFRICAN CATTLE IN BRITISH DEPENDENT TERRITORIES
}

$T$ HE primary purpose of a survey carried out by D. E. Faulkner, director of veterinary services, Nyasaland, and Dr. H. Fpstein, of the Hebrew University, Israel, was to describe the distinctive types and breeds of indigenous cattle found in British Dependent Territories of Africa*. Besides those of the Colonial territories, descriptions are included of the indigenous cattle of Southern Rhodesia (a selfgoverning British colony), the High Commission territories of Bechuanaland, Basutoland and Swaziland, and also of Libya and the Sudan. The cattle of the latter countries have been included because they help to throw light on the origins of the cattle of the Colonial territories adjacent or near them.

So far as possible, the types and breeds of cattle are described separately regardless of their territorial origin. In some cases it has been necessary to provide explanatory notes on the indigenous cattle of certain individual territories to make the existing situation clear. In the case of the Bechuanaland Protectorate and Southern Rhodesia, for example, owing to various historical movements and introduction of stock, the position would be confused without knowledge of the historical background.

The system of grouping and classification employed is as follows : all cattle have been grouped into three main geographical regions comprising East, Central and South Africa; West Africa; and North Africa.

The first of these regions, namely East, Central and South Africa, consists of three areas which are large and important regions in themselves. For the purpose of the survey it seemed better to group the three together in view of the extensive migratory movements of man and animals which, over the centuries,

* Colonial Office : Colonial Advisory Council of Agriculture, Animal Health and Forestry. Publication No. 5: The Indigenons Cattle of the British Dependent Territories in Africa, with material on certain other African Countries. Pp. xvili +18 and commencing in East Africa, have occurred in great waves down the continental backbone through central Africa to the south.

The origin and history of African cattle are dealt with in some detail. Epstein has devoted considerable study over many years to this most important subject and the form of classification employed in the publication is almost entirely the result of his work.

The foundation groups into which the various types have been classified are as follows:

\section{Humpless cattle:}

Longhorn humpless

Shorthorn humple.

Humped cattle :

Zebu cattle (1) Cervico-thoracic humped (neck-humped).

(2) Thoracic-humped (chest humped).

Sanga cattle (1) Cervico-thoracic humped (neck-humped). (2) Thoracic-humped (chest-humped).

In some regions no representatives of a group as such are now to be found, examples of this being the absence of longhorn humpless cattle in East, Central and South Africa, of the cervico-thoracic humped zebu in West Africa, and in North Africa the absence of every group except the shorthorn humpless cattle represented by the Libyan shorthorn.

Knowledge of the origin and history of African cattle types can play an important part in the efforts being made to improve them. From a slight study of the basic foundation groups from which the present breeds and sub-types of Africa have sprung, it is apparent that certain fundamental differences exist between them. To appreciate the genetical potentialities of these breeds and types it is important to know as much as possible not only of the parent stocks from which they came, but of the environmental conditions under which they and their parent stocks developed. Such knowledge is also of value when assessment has to be made of the effects of cross-breeding which has taken place over a long period between various breeds and sub-types. 